\title{
Parameters of electrostatic spraying and its influence on the application efficiency ${ }^{1}$
}

\author{
Robson Shigueaki Sasaki², Mauri Martins Teixeira ${ }^{3}$, Haroldo Carlos Fernandes ${ }^{4}$, \\ Paulo Marcos de Barros Monteiro ${ }^{5}$, Denílson Eduardo Rodrigues ${ }^{6}$, Cleyton Batista de Alvarenga
}

\begin{abstract}
When the electrostatic spraying is used correctly, it provides advantages over conventional systems, however many factors can affect the system efficiency. Therefore, the objective of this study was to evaluate the charge/mass ratio $(\mathrm{Q} / \mathrm{M})$ at different spraying distances $(0,1,2,3,4$ and $5 \mathrm{~m})$, and the liquid deposition efficiency on the target. Evaluating the Q/M ratio the Faraday cage method was used and to evaluate the liquid deposition efficiency the artificial targets were positioned longitudinally and transversely to the spray jet. It was found that the spraying distance affects the $\mathrm{Q} / \mathrm{M}$ ratio, consequently, the liquid deposition efficiency. For the closest distance to the target the $\mathrm{Q} / \mathrm{M}$ ratio was $4.11 \mathrm{mC} \mathrm{kg}^{-1}$, and at distances of $1,2,3,4$ and $5 \mathrm{~m}$, the ratio decreased to $1.38,0.64,0.31,0.17$ and 0.005 $\mathrm{mC} \mathrm{kg}{ }^{-1}$, respectively. For the liquid deposition, the electrostatic system was affected by the target orientation and spraying distance. The target transversely to the jet of liquid did not improve the liquid deposition, but longitudinally increased the deposition up to 3 meters of distance.
\end{abstract}

Key words: charge/mass ratio, liquid of deposition, efficiency in the electrostatic spraying.

\section{RESUMO}

\section{Parâmetros da pulverização eletrostática e sua influência na eficiência de aplicação}

A pulverização eletrostática, quando utilizada de maneira correta, proporciona vantagens em relação aos sistemas convencionais. No entanto, diversos fatores podem interferir na eficiência do sistema. Por isso, objetivou-se, com este trabalho, avaliar a relação carga/massa (Q/M) em diferentes distâncias de pulverização $(0,1,2,3,4$ e $5 \mathrm{~m})$ e a eficiência de deposição de líquido no alvo. Na avaliação da relação Q/M, utilizou-se o método da gaiola de Faraday e, na avaliação da eficiência da deposição de líquido, posicionaram-se alvos artificiais, nos sentidos longitudinal e transversal ao jorro de pulverização. Verificou-se que a distância de pulverização afeta a relação Q/M e, consequentemente, a eficiência na deposição de líquido. Na distância próxima ao alvo, a relação $Q / M$ foi de $4,11 \mathrm{mC} \mathrm{kg}^{-1}$, e, nas distâncias de $1,2,3,4$ e 5 m, reduziu-se para 1,$38 ; 0,64 ; 0,31 ; 0,17$ e $0,005 \mathrm{mC} \mathrm{kg}^{-1}$, respectivamente. Quanto à deposição de líquido, $\mathrm{o}$ sistema eletrostático foi afetado pela orientação em relação ao alvo e pela distância de pulverização. Com o alvo na transversal, o sistema não proporcionou aumento da deposição de líquido, já com o alvo na longitudinal, houve aumento na deposição até a distância de $3 \mathrm{~m}$.

Palavras-chave: relação Q/M, deposição de líquido, tecnologia de aplicação de agrotóxicos.

\footnotetext{
Recebido para publicação em 31/10/2012 e aprovado em 04/04/2013

1 Part of the Master's thesis of the first author.

2 Agronomist Engineer, Master of Science. Departamento de Engenharia Agrícola, Universidade Federal de Viçosa, Campus Viçosa, Avenida Peter Henry Rolfs, s/n, 36570-000,

Viçosa, Minas Gerais, Brazil. robsonsasaki@yahoo.com.br (corresponding author)

${ }^{3}$ Agronomist Engenieer, Doctor of Science. Departamento de Engenharia Agrícola, Universidade Federal de Viçosa, Campus Viçosa, Avenida Peter Henry Rolfs, s/n, 36570-000, Viçosa, Minas Gerais, Brazil. mauri@ufv.br

${ }^{4}$ Agriculture Engineer, Doctor of Science. Departamento de Engenharia Agrícola, Universidade Federal de Viçosa, Campus Viçosa, Avenida Peter Henry Rolfs, s/n, 36570-000, Viçosa, Minas Gerais, Brazil. haroldo@ufv.br

${ }^{5}$ Electrical Engineer, Doctor of Science. Departamento de Engenharia Elétrica, Universidade Federal de Viçosa, Campus Viçosa, Avenida Peter Henry Rolfs, s/n, 36570-000, Viçosa, Minas Gerais, Brazil. paulo@em.ufop.br

${ }^{6}$ Electrical Engineer, Doctor of Science. Departamento de Engenharia Elétrica, Universidade Federal de Ouro Preto, Centro de Convergência, Campus Morro do Cruzeiro, 35400000, Ouro Preto, Minas Gerais, Brazil. deduardo@ufv.br

${ }_{7}^{7}$ Agronomist Engineer, Doctor of Science. Departamento de Engenharia Agrícola, Universidade Federal de Viçosa, Campus Viçosa, Avenida Peter Henry Rolfs, s/n, 36570-000, Viçosa, Minas Gerais, Brazil. cleytonbatista@yahoo.com.br
} 


\section{INTRODUCTION}

The use of pesticides should be performed efficiently, since its application without the appropriate technology can cause contamination of the environment, leaving residues in food and increase the risk of poisoning of farm workers.

There are some reports of inefficient sprayings, in excess or with deficit of the active ingredient on the target, and in some cases, more than $50 \%$ of the pesticides used are wasted because they do not reach the desired targets, causing environmental issues and inefficiency of spraying. Chaim et al. (1999), studying tomato and bean crops, observed losses between 59 and $76 \%$ depending on the size of the plants. In vines, Chaim et al. (2004) observed losses of up to $39 \%$, varying according to the equipment used.

With the objectives of overcome the application issues, increase the spraying efficiency, reduction of costs and decrease environmental impacts, some technologies have emerged. Among them, it is worth highlighting the precision equipment for use at variable rates, the use of embedded technology, the light bars, the autopilot and also electrification of droplets through electrostatic sprayers.

The electrostatic sprayer is a system that electrically charges the drops. According to Chaim (2006), the attraction force of a charged particle to a plant consists of two parts. The first is due to the action of the electrostatic field of the particle itself, in relation to its approach to the plant surface. The second part is the action of the electric field forces of the spray tip and the cloud upon the electric field of the drop. If the electric fields are directed to the plant, the drops will be projected on its surface.

Currently, due to environmental and economic issues, one has sought to reduce losses in a spray, and the electrostatic spraying, if applied properly, can be an alternative to reduce these losses. In Brazil, the electrostatic spraying is a little used technique by the farmers. Several researchers have shown that, when it is used correctly, this technology can bring benefits in the application of pesticides.

Maynagh et al. (2009) reported that among the advantages of electrostatic spraying is the increase of the efficiency, either on the deposition of agrochemicals and on the reduction of drift. Maski \& Durairaj (2006) observed na increase of $42 \%$ in the control of aphids using the electrostatic spraying when compared to the conventional system. Xiongkui et al. (2011) increased the target deposition rate up to $50 \%$ when compared to the conventional system of spraying. Laryea \& No (2005) found an increase of up to 2.51 times on the deposition of liquid using the electrostatic spraying when compared to the results obtained by the use of the conventional system.

However, it is noteworthy that there are also studies performed with electrostatic spraying which provided no improvement in the application of pesticides, such as those conducted by Silva et al. (1997), Silva et al. (2000), Bayer et al. (2011) and Magno Júnior et al. (2011).

The failure of electrostatic spraying can be due to several factors. Maski \& Durairaj (2010) observed that the tension applied in the electrode of drops charging induction, the application speed, the height of the spraying bar in relation to the target and the orientation in relation to the target, affected the electrostatic spraying.

For those reasons, the objective of this study was to evaluate the factors that affect the electrostatic spraying, specially the effect of the distance between the spray tip and the target, as the ratio charge/mass $(\mathrm{Q} / \mathrm{M})$ and the liquid deposition under different positions relative to the target (longitudinal and transverse).

\section{MATERIAL AND METHODS}

The experiment was carried out on the Laboratory of Agricultural Spraying (LADA), at Universidade Federal de Viçosa, Viçosa- Minas Gerais.

To perform the experiment, it was used an electrostatic spray of the brand Eletrostatic Spraying Systems, model ESS MBP 4.0, with $15 \mathrm{~L}$ capacity. This spray uses the pneumatic principle for formation and fractionation of the droplets; moreover it uses the method of indirect induction of charges for electrification of the drops.

To determine the intensity of the charge, the method of Faraday Cage, isolated and earthed by a multimeter, was used.

The sprayings were performed inside the cage, using a multimeter of the brand Minipa and model ET-2510 with accuracy of $\pm 1 \%$, to the readings of current (A). All the essays were performed with the spray battery completely charged. Aiming to assess the charge of the drops under different distances, the sprayings were performed at $0 ; 1$; 2; 3; 4 and $5 \mathrm{~m}$ of the Faraday Cage. For every treatment, the sprayer was put up at full throttle of the engine, taking the time of 15 seconds to stabilize the equipment before the spraying was proceeded. Afterwards, the amount of liquid spayed $\left(\mathrm{L} \mathrm{min}^{-1}\right)$ was measured using a graduated cylinder with precision of $5 \mathrm{~mL}$.

From the data of the electric current and the amount of liquid sprayed, the charge/mass ratio in the drop was determined (Equation 1).

$\mathrm{Q} / \mathrm{M}=\frac{\mathrm{i}}{\mathrm{m}}$

Where:

$\mathrm{Q} / \mathrm{M}=$ charge/mass ratio $\left(\mathrm{C} \mathrm{kg}^{-1}\right)$;

$\mathrm{i}=$ Electric current on the spray jet $\left(\mathrm{C} \mathrm{s}^{-1}\right)$; and,

$\mathrm{m}=$ Liquid flow $\left(\mathrm{kg} \mathrm{s}^{-1}\right)$. 
To obtain the flow unit in $\mathrm{kg} \mathrm{min}^{-1}$, it was agreed that the specific mass of the water was one. The sprayings were performed under laboratory conditions using a digital anemometer of the brand Kestrel, model Kestrel 1000, and a thermo-hygrometer of the brand Betha, model Ummi; the weather conditions were monitored during the essays. The experimental design was a completely randomized, with 14 replicates for each treatment. The statistical analysis were performed through the program Sisvar version 5.3.

To assess the influence of the distance of the target on the efficiency of droplets deposition using the electrostatic spraying, the spray was built on a base, remaining stationary during the spraying performance.

Were used artificial targets made of wood, where grounded metal plaques were fixed. Two metal plaques were fixed on each target, being one of them transverse and the other one longitudinal to the spraying jet. On those plaques were fixed plastic labels of $14.5 \times 3 \mathrm{~cm}$, which were used to determine the spray deposition.

The sprayings were performed in five longitudinal distances $(1 ; 2 ; 3 ; 4$ and $5 \mathrm{~m})$, as shown on Figure 1.

It is worth mentioning that during the evaluations of liquid deposition using the spectrophotometer methodology, no pattern was set to the size of the target, thus, it was used the size of the plastic labels. According to two preliminary essays using smaller labels with $2.5 \mathrm{x}$ $2.5 \mathrm{~cm}$ and $7.5 \times 2.5 \mathrm{~cm}$, the absorbance reading after the spraying were from 0.005 to $0.017 \mathrm{~nm}$ and, according to the spectrophotometer manufactures specifications, the reading accuracy is $\pm 0.002 \mathrm{~nm}$. Thus, the evaluations could be compromised, especially those that presented lower values.

The sprayings were performed with the electrostatic system switched on and off, and subsequently, the spray deposition on both systems was compared. The experiment was conducted in a completely randomized design on a factorial scheme $2 \times 5$, consisted of two spraying system (electrostatic system switched on/off) and five horizontal distances, with the target placed transversely and longitudinally to the spray jet, totalizing 80 experimental units.

At each spraying performance, the sprayer was turned on for 15 seconds until the stabilization of the air and liquid flow. Afterwards, the spraying was carried out for 3 seconds. The spraying time was chosen according to the preliminary essays, which showed that when the spraying time was less than 3 seconds, the absorbance values were low, especially for distances greater than $2 \mathrm{~m}$, and as mentioned before, the evaluations could be compromised. Although, when spraying for more than 3 seconds, losses occurred at the distances of 1 and $2 \mathrm{~m}$, due to the spray draining.

To evaluate the spray deposition, the methodology suggested by Palladini (2000) was used. The pigment used was the bright blue (Blue pigment FCF, Duas Rodas Industrial), internationally cataloged by "Food, Drug \& Cosmetic" as FD\&C Blue n.1.

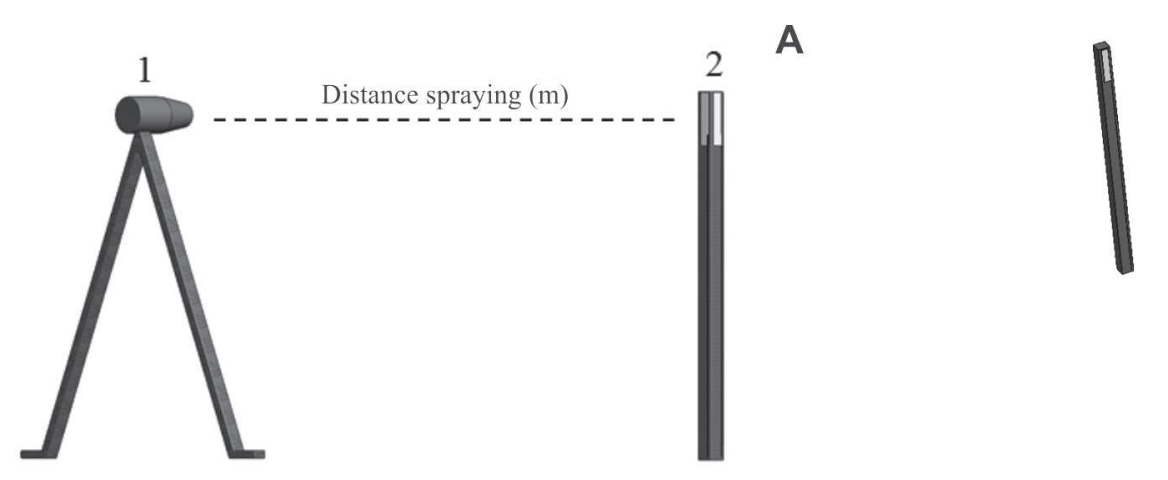

C
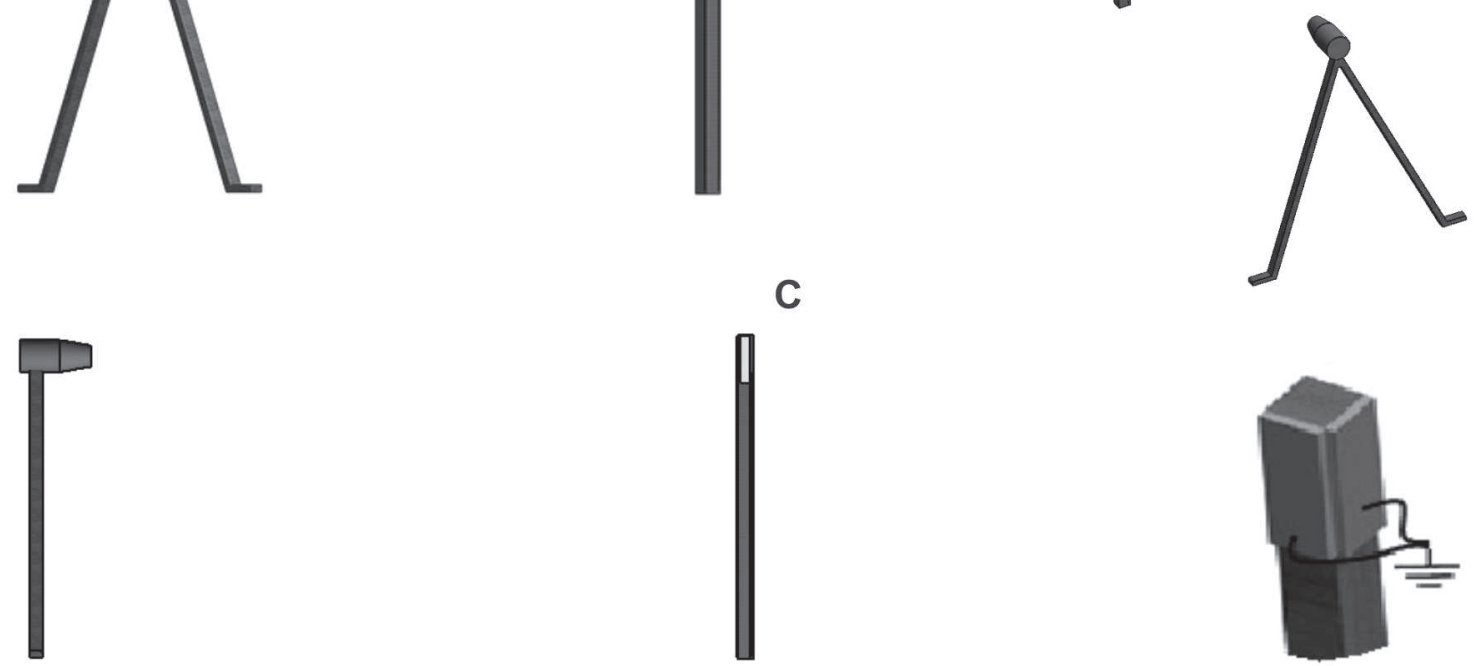

Figure 1. Scheme of the target and sprayer position during the liquid deposition evaluations. (1) Sprayer nozzle; (2) Spraying target; (A) e (B) Three dimensions perspectives; (C) Frontal view; (D) Target details. 
At first, $3 \mathrm{gL}^{-1}$ of the pigment was added to the spray, and from this mixture, samples of $1 \mathrm{~mL}$ were taken, from which 13 dilutions on distilled water were performed, consisting the subsamples. The absorbance of the subsamples were assessed using a spectrophotometer Biospectro, model SP-22, properly calibrated and adjusted for absorbance readings in the range of $630 \mathrm{~nm}$. Knowing the concentration of the samples and the volume of the dilutions, it was possible to determine the concentration of the subsamples $\left(\mathrm{mg} \mathrm{L}^{-1}\right)$ and, in addition to the absorbance values, the calibration curve of the pattern solution was built.

After he sprayings, the labels were packed in plastic bags and $50 \mathrm{~mL}$ of distilled water were added and agitated for 30 seconds. Afterwards, one sample was taken and assessed on the spectrophotometer. From the absorbance readings and using the calibration curve of the pattern solution, the absorbance data were transformed in concentration values $\left(\mathrm{mg} \mathrm{L}^{-1}\right)$. With the initial pigment concentration data, the volume of the dilution used to wash the samples and the concentration detected by the spectrophotometer, it was possible to determine the volume captured by the target (Equation 2).

$\mathrm{Ci} \mathrm{Vi}=\mathrm{Cf} \mathrm{Vf}$

Where:

$\mathrm{Ci}=$ Inicial concentration of the sample $\left(\mathrm{mg} \mathrm{L}^{-1}\right)$;

$\mathrm{Vi}=$ Volume captured by the target $(\mathrm{mL})$;

$\mathrm{Cf}=$ Concentration of the sample $\left(\mathrm{mg} \mathrm{L}^{-1}\right) ; \mathrm{e}$,

$\mathrm{Vf}=$ Volume of the dilution $(\mathrm{mL})$.

Finally, the spray deposition $\left(\mu \mathrm{L} \mathrm{cm}^{-2}\right)$ was determined using the data from the volume of spray captured by the target. The results were analysed through the program Sisvar, version 5.3.

\section{RESULTS AND DISCUSSION}

During the evaluation of charge/mass ratio under differetn spraying distances, the temperature remained between 15 and $16{ }^{\circ} \mathrm{C}$, and the relative humidity was between 79 and $81 \%$, with absence of wind.

It was noticed that the charge/mass ratio was inversely proportional to the distance between the spray tip and the target. When spraying at the minimum distance from the target, the charge/mass ratio was $4.11 \mathrm{mC} \mathrm{kg}^{-1}$, while for the distance of $5 \mathrm{~m}$, the ratio was $0.052 \mathrm{mC} \mathrm{kg}^{-1}$ (Figure 2). Similar results were found by Moon et al. (2003) e Zhao et al. (2008).

The greater is the distance from the target, the greater is the path to be traveled by the drop, and in this way the drop faces air resistance, which causes loss of electric charge present in the droplets, causing the reduction in the charge/mass ratio. Further, as it moves away from the target, smaller droplets tend to evaporate during the trajectory, which can also affect the charge/mass ratio.

In electrostatic spraying, the greater is the charge/ mass ratio, the greater is the spraying efficiency, as the droplets charge affects the electrical power, which affects the electrostatic field between the drop and the target.

There is no ideal charge/mass ratio for spraying, however, the higher is the ratio, the better is the efficiency of electrostatic spraying. According to Carlton et al. (1995), the minimum charge/mass ratio in electrostatic spraying for obtaining significant gains on drops deposition on the targets is $0.8 \mathrm{mC} \mathrm{Kg}^{-1}$. Law (1995) states that the minimum charge/mass ratio is from 1 to $2 \mathrm{mC} \mathrm{kg}^{-1}$. Although these values can be used as references, recent studies have shown that these lower values caused an increase of spray deposition on the target (Laryea \& No, 2005).

During the evaluation of liquid deposition, the temperature varied between 15 and $19^{\circ} \mathrm{C}$, and the relative humidity varied from 76 to $83 \%$, with absence of wind. The calibration curve showed high correlation between the pigment concentration and the absorbance (Figure 3 ).

An interaction between the spray system and the distance was observed, proceeding thus the deployment of the interactions among the factors. For the spraying system deployment (switched on/off), among each level of longitudinal distance, the average test was applied to verify the electrostatic spraying effect. It was noticed that, when the target was placed transversely, the effect of the electrostatic system was less prominent, compared to the effect of the target placed longitudinally.

Although the drop deposition increased with the target in the transversal position and the system switched on in the most of the cases, these increases don't differ statistically (Table 1).

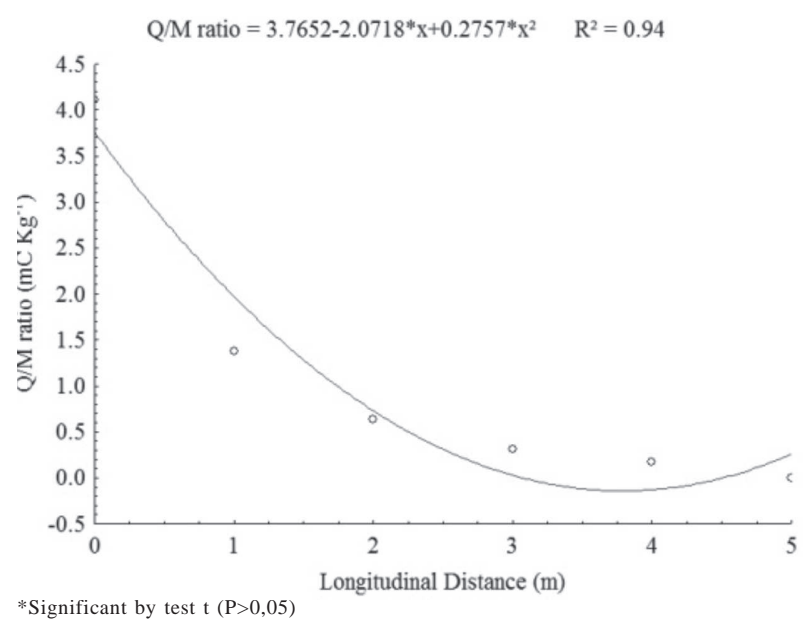

Figure 2. Q/M ratio at different distances between the sprayer and the target. 


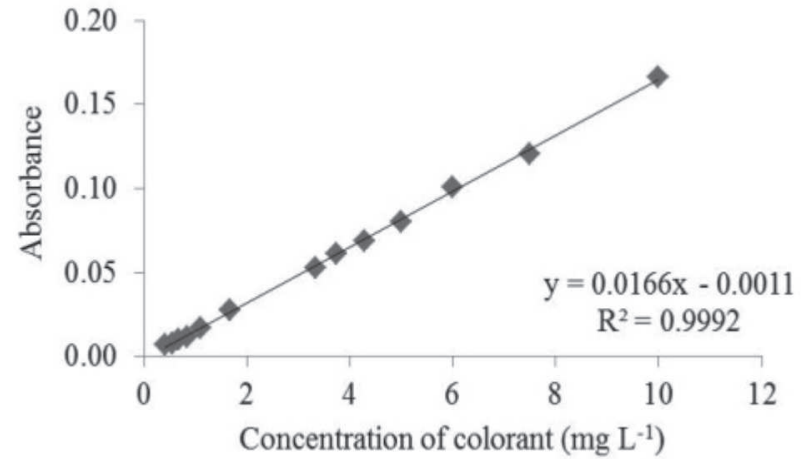

Figure 3. Calibration for the pattern solution.

The position of the target in relation to the jet spray affects the deposition during the spraying. Marchi et al. (2005) observed that the angle of the leaf in Eichhornia crassipes affected the spray deposition. Maski \& Duraijaj (2010) observed that the orientation direction regarding the target, in relation to the spraying, affected the electrostatic spraying, corroborating the present study.

On a spray performance, depending on the target angle and on the distance of the pneumatic nozzle, the direct impact of the drop occurs or, the pneumatic strength is greater than the electrical power, making the electrostatic spraying cause no positive effects. In the present study, the use of the target transversely did not provide increase on the spray deposition, and for this reason, only the target in the longitudinal position was considered for analyses.

With the target longitudinally in relation to the spray jet, it was observed that the electrostatic spraying system increased the deposition up to the distance of $2 \mathrm{~m}$, and from this point, there were no significative gain on deposition with the system (Table 2).

The reduction of the electrostatic system efficiency can be due to the $\mathrm{Q} / \mathrm{M}$ ratio, because as observed, for the distances 1 and $2 \mathrm{~m}$, the $\mathrm{Q} / \mathrm{M}$ ratio were 1.38 and 0.6 , respectively. For the distances 3,4 and $5 \mathrm{~m}$, the $\mathrm{Q} / \mathrm{M}$ ration were $0.3,0.17$ and $0.005 \mathrm{mC} \mathrm{Kg}^{-1}$, and this is the reason why the electrostatic system did not provide increases on the liquid deposition. There are many different opinions regarding to the minimum values for $\mathrm{Q} / \mathrm{M}$ ratio in order to provide significant gains on the spray deposition. The charge/mass ratio that provided an increase of spray deposition on the target was $0.6 \mathrm{mC}$ $\mathrm{Kg}^{-1}$, a value approximated to those reported by Carlton et al. (1995).

Confirming the previous results, when performing the deployment of the spraying distance for each system, the analyses were performed using regression. It was observed a tendency of increase de deposition by the electrostatic system at distances up to $3 \mathrm{~m}$ in the longitudinal orientation (Figure 4).

In a spraying performance, when the hydraulic principle is used on the drops fragmentation, the distance from the spray tip to the target is usually $0.5 \mathrm{~m}$, due to the uniform liquid distribution and to the deposition range.

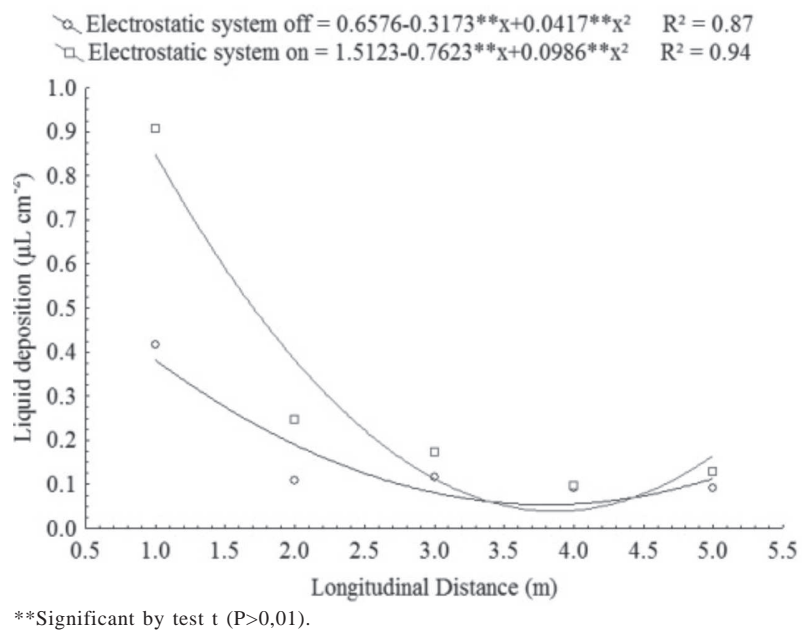

Figure 4. Liquid deposition according to the distance and to the spraying system.

Table 1. Liquid deposition $\left(\mu \mathrm{L} \mathrm{cm}^{-2}\right)$ at different distances, with the target transversal to the spraying jet

\begin{tabular}{lccccc}
\hline \multirow{2}{*}{ Electrostatic system } & \multicolumn{5}{c}{ Distance (m) } \\
\cline { 2 - 6 } & $\mathbf{1}$ & $\mathbf{2}$ & $\mathbf{3}$ & $\mathbf{4}$ & $\mathbf{5}$ \\
\hline Switched on & $4.49 \mathrm{~b}$ & $1.57 \mathrm{a}$ & $0.45 \mathrm{a}$ & $0.21 \mathrm{a}$ & $0.2 \mathrm{a}$ \\
Switched off & $5.06 \mathrm{a}$ & $1.28 \mathrm{a}$ & $0.42 \mathrm{a}$ & $0.13 \mathrm{a}$ & $0.1 \mathrm{a}$ \\
\hline
\end{tabular}

Averages followed by the same letter in the column do not differ by the test $\mathrm{F}(\mathrm{P}>0,05)$.

Table 2. Liquid deposition $\left(\mu \mathrm{L} \mathrm{cm}^{-2}\right)$ at different distances, with the target longitudinal to the spraying jet

\begin{tabular}{lccccc}
\hline \multirow{2}{*}{ Electrostatic system } & \multicolumn{5}{c}{ Distance (m) } \\
\cline { 2 - 6 } & $\mathbf{1}$ & $\mathbf{2}$ & $\mathbf{3}$ & $\mathbf{4}$ & $\mathbf{5}$ \\
\hline Switched on & $0.91 \mathrm{a}$ & $0.25 \mathrm{a}$ & $0.17 \mathrm{a}$ & $0.10 \mathrm{a}$ & $0.13 \mathrm{a}$ \\
Switched off & $0.42 \mathrm{~b}$ & $0.11 \mathrm{~b}$ & $0.12 \mathrm{a}$ & $0.09 \mathrm{a}$ & $0.09 \mathrm{a}$ \\
\hline
\end{tabular}

Averages followed by the same letter in the column do not differ by the test $F(P>0,05)$. 
Yet, when using the conventional pneumatic principle, the useful range of application is variable depending on the treatment to be performed and, in general, has a wide application range. However, when combining the electrostatic and the pneumatic systems to determine the useful range of spraying, it must be considered, besides the treatment to be performed, the distance at which the electrostatic system will be more efficient.

\section{CONCLUSIONS}

The $\mathrm{Q} / \mathrm{M}$ ratio is inversely proportional to the distance between the sprayer and the target.

The system was more efficient regarding to drops deposition when the target was longitudinal to the spray jet.

The minimum $\mathrm{Q} / \mathrm{M}$ ratio on which the liquid deposition was increased by the electrostatic system was $0.6 \mathrm{mC} \mathrm{kg}^{-1}$.

\section{REFERENCES}

Bayer T, Costa IFD, Lenz G, Zemolin C, Marques LN \& Stefanelo MS (2011) Equipamentos de pulverização aérea e taxas de aplicação de fungicida na cultura do arroz irrigado. Revista Brasileira Engenharia Agrícola Ambiental, 15:192-198.

Carlton JB, Bouse LF \& Kirk IW (1995) Electrostatic charging of aerial spray over cotton. Transactions of the ASAE, 38:16411645.

Chaim A (2006) Pulverização eletrostática: Principais processos utilizados para a eletrificação de gotas. Embrapa Meio Ambiente. $17 \mathrm{p}$. (Documento 57).

Chaim A, Castro VL, Corrales F, Galvão JAH \& Cabral OMR (1999) Método para monitorar perdas na aplicação de agrotóxicos na cultura do tomate. Pesquisa Agropecuária Brasileira, 34:741-747.

Chaim A, Pessoa MCPY \& Ferracini VL (2004) Eficiência de deposição de pulverização em videira comparando bicos e pulverizadores. Pesticidas: revista de ecotoxicologia e meio ambiente, 14:39-46.

Laryea GN \& No SY (2005) Effect of fan speed and electrostatic charge on deposition of orchard canopy sprays. Atomization and Sprays, 15:133-144.

Law SE (1995) Electrostatic atomization and spraying, In: Chang AJ \& Kelly JM Crowley (Eds.) Handbook of Electrostatic Processes. Marcel Dekker, New York. p.413-440.

Magno Junior R, Teixeira MM, Vieira LB, Ferreira LR \& Alvarenga CB (2011) Desenvolvimento de um dispositivo eletrônico para atração de gotas da aplicação eletrostática em plantas cítricas. Bioscience Journal, 27:798-804

Marchi SR, Martins D, Costa NV, Carbonari CA \& Terra MA (2005) Depósitos de calda de pulverização nas faces adaxial e abaxial de folhas de Eichhornia crassipes dispostas em diferentes ângulos. Planta Daninha, 23:321-328

Maski D \& Durairaj D (2010) Effects of charging voltage, application speed, target height and orientation upon charged spray deposition on leaf abaxial and adaxial surfaces. Crop Protection, 29:134-141.

Maski D \& Durairaj D (2006) Abaxial deposition and biological efficacy of electrostatically charged spray. Transactions of the ASAE, 61:116.
Maynagh BM, Ghobadian B, Jahannama MR \& Hashjin TT (2009) Effect of Electrostatic Induction Parameters on Droplets Charging for Agricultural Application. Journal of Agricultural Science and Technology, 11:249-257.

Moon JK, Lee DH, Kang TG \& Yon KS (2003) A capacitive type of electrostatic spraying nozzle. Journal of Electrostatics, 57:363-379.

Palladini LA (2000) Metodologia para avaliação da deposição em pulverizações. Tese de Doutorado. Universidade Estadual Paulista, Botucatu. 116p.

Silva ORRF, Carvalho OS \& Marques L (2000) Determinação das perdas por escorrimento da pulverização eletrostática e convencional sobre o cultivo do algodoeiro herbáceo. Revista Brasileira de Oleaginosas e Fibrosas, 4:123-130.

Silva ORRF, Marques L, Carvalho OS \& Vieira RM (1997) Avaliação do depósito de gotas através da pulverização eletrostática e da convencional sobre a cultura do algodoeiro. Revista Brasileira de Engenharia Agrícola Ambiental, 1:101-105.

Xiongkui H, Aijun Z, Yajia L \& Jianli S (2011) Precision orchard sprayer based on automatically infrared target detecting and electrostatic spraying techniques. International Journal of Agricultural and biological engineering, 4:35-40.

Zhao S, Castle GSP \& Adamiak K (2008) Factors affecting deposition in electrostatic pesticide spraying. Journal of Electrostatics, 66:594-601. 